language in 3 volumes]. Kyiv. 2007. [in Ukrainian].

4. Rehulovani profesii: vzaiemodiia derzhavy, robotodavtsiv, zakladiv osvity ta profesiinykh spilnot dlia dosiahnennia krashchykh rezultativ- obhovorymo proekt MON [The regulated professions: the interaction of the state, employers, educational institutions and professional communities to achieve the better results - we will discuss the project of the
Ministry of Education and Science]. [Electronic resource]. Available at: http://www.osvita.org.ua/ news/80249.html [in Ukrainian].

5. Cox Janell 10 Useful Skills Modern Teachers Need. [Electronic resource]. Available at: https://www.thoughtco.com/ useful-skills-modern-teachers-need-2081527 [in English].

6. The International Foundation of Medicine (IFOM). [Electronic resource]. Available at: https:// www.nbme.org/ifom/ [in English].

Стаття надійшла до редакції 19.06.2019

УДК 378.145.026:81.111

DOI:

Наталія Жорняк, кандидат педагогічних наук, доцент, доцент кафедри іноземних мов Національного університету “Львівська політехніка"

\title{
МІЖНАРОДНИЙ ДОСВІД ОСВІТНІХ ПРОГРАМ ДЛЯ КОРІННИХ НАРОДІВ
}

У статті розглянуто міжнародний досвід створення умов та впровадження програм для покращення якості освіти корінних народів, подано характеристику ключових історичних етапів розвитку освіти корінних народів, дано визначення самому поняттю “корінні народи”. Детально вивчено основні напрямки та вжиті стосовно них заходи для забезпечення корінних жителів якісними освітніми можливостями. Особливу увагу приділено аналізу дипломних програм та освітніх проектів Канади та Австралії.

Ключові слова: освітня діяльність; корінне населення; спільнота; культурні відмінності; культурна відповідність; навчальний центр.

Jim. 16.

Nataliya Zhornyak, Ph.D.(Pedagogy), Associate Professor of the Foreign Languages Department, Lviv Polytechnic National University

\section{INTERNATIONAL PRACTICE OF IMPLEMENTING EDUCATIONAL PROGRAMS FOR INDIGENOUS PEOPLE}

The article deals with the international experience of creating conditions and implementing programs for improving the quality of education of indigenous peoples, the key historical stages of development of indigenous peoples' education are described; the concept "indigenous peoples" is defined. Among the main obstacles encountered on the way to the education of indigenous peoples, the historical social, geographical, demographic, cultural and individual ones were highlighted. The main directions and measures taken to provide indigenous peoples with high-quality educational opportunities are studied in detail. Particular attention is paid to the analysis of diploma programs and educational projects in Canada and Australia. Over the past decades, indigenous education has undergone radical changes and has begun to respond to the philosophy and needs of indigenous people. Canada's history of indigenous education identifies four historical stages: the traditional, the period of industrial boarding schools run by the federal government, provincial school education, and the era of Indian control over Indian education. The history of the education of Australian Aborigines is traditionally divided into three stages - the missionary, protectionist, and assimilation; the latter, now being somehow smoothed by the cultural relevance approaches and attempts to meet the needs of communities. It is worth noting that indigenous peoples' involvement in educational programs takes place both explicitly and implicitly. On the one hand, higher educational establishments and schools create special conditions for admittance and learning for Aborigines. On the other hand, with the help of individual courses or modules, they acquaint others with the culture, customs and life of these peoples.

Keywords: educational activity; indigenous population; community; cultural differences; cultural correspondence; an educational center.

П остановка проблеми. Щоденна взаємодія з людьми, яким притаманні неоднакові цінності, соціальні звичаї та способи сприйняття реальності, стала безумовною нормою, а не винятком. Ера цифрових технологій та поглиблення глобалізаційних процесів в рази пришвидшили цю співдію та зумовили зростання культурної різноманітності населення та робочої сили. Тому здатність працювати у мультикультурному середовищі стає 
на сьогодні професійною необхідністю для багатьох фахівців. Роботодавці визнають перевагу працівників, які володіють культурною компетентністю, а також вона є частиною стандарту професійних вимог.

3 розвитком глобалізації також зросла потреба у визнанні значення внеску різних культур. Це особливо стосується культур корінних народів, які історично стикаються з багатьма проблемами в основному некорінної системи освіти, однією 3 яких є мовне питання: корінні народи повинні вивчати англійську або іншу мову, яка для них не $\epsilon$ рідною. Також раніше відбувалося насильницьке розлучення дітей аборигенів з їхніми сім'ями. Наприклад, школи-інтернати, ера яких почалася в 1892 р. указом місцевих представників влади і закінчилася в 1983 р. із закриттям останньої з них, мали негативний вплив на перші нації Канади [6].

Інші труднощі пов'язані 3 культурними відмінностями або негативними стереотипами. Студенти корінного населення мають менше можливостей і потреб скористатися навичками, здобутими в університеті у подальшому житті [16]. Крім того, багато корінних громад $\epsilon$ географічно віддаленими і не в змозі залучати та утримувати висококваліфікованих вчителів для своїх шкіл.

Мета цієї статті - проаналізувати позитивний міжнародний досвід створення умов та впровадження програм для покращення якості освіти корінних народів.

Огляд літератури. Населяючи великі території по всьому світу, корінні народи нараховують, за приблизними оцінками, близько 300 мільйонів чоловік [11]. Кожна держава у своїх статутних документах чітко прописує які сам етногрупи вважаються корінними. Так, корінними народами Канади (згідно з Канадським Законом про мультикультурність та іншими правовими документами) прийнято вважати різноманітні племена індіанців, інуітів та метисів, які проживають на території Канади. Зараз їхня чисельність становить трохи більше семисот тисяч [13]. Корінним населенням Австралії вважають австралійських аборигенів, представників окремої австралоїдної раси, чисельність яких у 2016 році становила 798 тис. осіб [9].

Ці народи називають корінними, бо вони жили на своїх землях до появи переселенців 3 інших районів, причому у подальшому останні посіли панівне положення шляхом завоювань, окупації, колонізації чи якимись іншими способами. Саме тому, на сьогодні ці народи, розосереджені в різних регіонах планети, перебувають у найбільш проблемному становищі порівняно 3 іншим населенням. Зберігаючи соціокультурні особливості, дані етногрупи постійно стикаються з необхідністю захисту своїх прав як самостійних народів. Вони прагнуть визнання своєї самобутності та способу життя, зокрема своїх підходів до передачі знань. Попри те, що низка подібних етнонаціональних спільнот має досить давнє походження, світова спільнота тільки в ХХ столітті зосередилося на вирішенні проблем їхнього збереження.

Проблема вимирання мов і культур корінних народів полягає ще й в тому, що їх неможливо підтримувати чи врятувати ззовні, тобто за підтримки інших країн. Джерело традиційних знань і вчень вмирає разом зі старійшинами, бо у цих культурах переважає усна передача знань. А оскільки вже декілька поколінь були виховані на чужинських переконаннях та цінностях, то зараз, як зазначає канадська вчена Барбара Барнебі, “ми маємо покоління, яке не належить до жодної культури - нащадки корінних жителів так і не стали повністю європейцями, але втратили своє власне традиційне бачення світу” [3].

Серед основних перешкод, що трапляються на шляху до освіти корінних жителів варто виділити iсторичні (внаслідок асиміляційної політики, яка велась саме через освітні заклади, освіта європейського типу сприймається з ворожістю та недовірою) [13], соціальні (дискримінація, культурна нечутливість, брак академічної підготовки, необхідність відмовлятися від своєї культури, традицій і переконань та осягати нову форму реальності) [10], географічні (місця післяшкільного навчання розташовані зазвичай далеко від місця проживання спільноти, а урядова стипендія лише часто покриває витрати) [2], демографічні (більшість корінних студентів починають навчання у зрілому віці, більшість студентів (80\%) - це жінки, в яких є сім'ї, матеріально від них залежні, цього факту програми розвитку корінного населення часто не враховують [14], культурні (зазвичай уклад навчального закладу не має нічого спільного з цінностями та переконаннями корінних жителів), індивідуальні (слабка мотивація та низька самооцінка) [15].

Для корінних народів загальна, проєвропейська освіта та їі ідеали успіху історично означали політику знищення та асиміляції - знищення ідентичностей корінних народів, мов і культурних практик, асиміляцію в західні та загально визнані як домінуючі суспільства. Існують численні приклади впливу цього процесу у всьому світі на культури, мови, психіку, екологію та суверенітет корінних народів. Колоніальний метод виховання 
місцевих мас ніколи не був спрямований на забезпечення рівного ставлення до корінного населення, він лише надавав їм достатньо освіти щоб підготувати їх як хороших робітників і утримував від бунту проти влади [5]. Як наслідок, сім'я та громада корінних жителів як життєво важливі учасники процесу, що сприяють розвитку власних дітей, були недооцінені або виключені зі сталого освітнього процесу. У кращому випадку культури та мови корінних народів розглядаються як інструменти для досягнення домінуючих цілей у сфері освіти, таких як оволодіння грамотністю та викорінення бідності.

Культурна релевантність часто використовується в школах лише як інструмент домінуючих ідеологій, який сприяє розумінню того, що означає бути успішним членом суспільства, і тому навчання стало своєрідною панацеєю для економічної стабільності, екологічної стійкості, розвитку та національної безпеки. Критеріями успішності ставали, звичайно ж, європейські мірила. I, попри всю свою важливість, вони, замість того, щоб чинити позитивний вплив на розвиток освіти та спільноти, були звичайними механізмами запровадження домінуючих концепцій.

Основний виклад. У всьому світі навчання в основному є відповідальністю держави. А універсальні цілі забезпечення базової освіти все ще перебувають на етапі обговорення того, як ефективно використовувати місцеві знання задля підтримки пріоритетів місцевої спільноти. Протягом останніх десятиліть освіта корінного населення зазнала радикальних змін і почала відповідати філософії і потребам корінного народу. Те, що відбувається в освіті сьогодні, визначає бачення майбутнього корінними жителями. В історії освіти корінних жителів Канади визначають чотири історичні етапи: традиційний, період промислових шкіл-інтернатів, якими керував федеральний уряд, провінційна шкільна освіта та епоха індіанського контролю над індіанською освітою [11]. Історію освіти австралійських аборигенів традиційно поділяють на три етапи місіонерський, протекціоністський та асиміляційний [4], щоправда останній на сьогодні намагаються дещо згладити культуровідповідністю та потребами спільнот. Для дослідження нами були обрані саме ці дві країни, де запровадження спеціальних умов та програм навчання корінного населення було успішним.

Враховуючи складні історичні взаємовідносини між європейськими емігрантами та корінним населенням, питанню соціалізації цієї верстви приділяється особлива увага. Останні десятиліття кількість студентів з числа корінного населення значно зросла, хоча їхня кількість, порівняно 3 іншими студентами, все ще незначна. Причиною цього $є$ бідність та безробіття серед корінних жителів, їхня низька самооцінка, культурна невідповідність вищих навчальних закладів їхньому світосприйняттю, низький рівень довузівської підготовки та упереджене ставлення до навчальних закладів через асиміляційну політику.

Одним із заходів для покращення ситуації із залученням корінних спільнот до освітнього процесу є впровадження та підтримка місцевого навчання. Місцева освіта характеризується як взаємозв' язок студентських, педагогічних, шкільних, громадських та місцевих ресурсів. Вона грунтується на ресурсах, проблемах та цінностях місцевої громади, спрямованих на заохочення партнерства навчальних закладів та громад, які включають екологічну, культурну, соціальну, економічну та політичну перспективи [4].

Наприклад, Рада Канади з питань розвитку людських ресурсів започаткувала цілу низку програм для економічного розвитку індіанських спільнот у кожній окремій провінції та території. Одна із провінцій Канади - Нова Шотландія прагне зробити освітуі навчання доступнішими в таких громадах за рахунок використання нових технологій і підвищення якості та ефективності системи освіти шляхом їі реструктуризації. Розвиток культури навчання дасть змогу всім жителям Нової Шотландії брати участь у зміні глобальної економіки [12]. Північно-Західні Території також скеровують свої зусилля на використання інформаційних мереж для підтримки особистісного розвитку та навчання, а також впровадження інноваційних підходів до реалізації програм. У рамках цього підходу Департамент освіти розробляє комп'ютерні операційні системи мовами аборигенів і сприяє тому, щоб люди в усіх громадах ПЗТ будуть мати доступ до інформаційних мереж [8].

Туристські послуги, які може забезпечити корінне населення, становлять значну і унікальну нішу в сфері туризму Канади. Профільний комітет Британської Колумбії, який займається питаннями розвитку корінного населення, розробив низку основних положень для забезпечення корінних жителів вищою туристською освітою, обгрунтування кожного положення та рекомендації щодо їх впровадження. Серед них найважливіші - визнання історії корінних народів, визнання історії освіти корінних народів, визнання цінностей та переконань корінних жителів як ключових складових їхньої освіти та застосування протоколу корінних жителів [7]. Дотримання цих положень 
забезпечує культуровідповідну підготовку студентів, а також допомагає пристосовуватись до потреб диверситивних спільнот Британської Колумбіі.

Варто зауважити, що залучення корінного населення до освітніх програм відбувається як експліцитно, так і імпліцитно. 3 одного боку, виші та школи створюють спеціальні умови вступу та навчання для аборигенів. 3 іншого - за допомогою окремих курсів чи модулів знайомлять інших 3 культурою, звичаями та побутом цих народів. Так, представниками провідних канадських вищих навчальних закладів (коледж Капілано, Рокі коледж, коледж Нової Каледонії, університет Маласпіна, Центр освіти корінних народів, коледж Нос Айленд, Коледж спільноти Носвест, коледж Селкірк, університет Томпсон Ріверз, Північний університет Британської Колумбії) було розроблено дипломну програму за напрямом "Туристична діяльність корінного населення", обов'язковими спеціалізованими предметами якого $є$ "Вступ до відносин у громаді корінного населення і культурний туризм”, “Історія відносин між корінними і некорінними жителями Канади” та "Розроблення автентичного туристського продукту для корінних жителів” [1]. Окрім того, більшість провідних університетів, а також коледжів Канади мають відділи, які займаються вивченням культури і побуту корінних жителів (Aboriginal Studies Departments) і на сайті майже кожного 3 них можна знайти спеціальні умови вступу для корінних жителів (Aboriginal Access Programs). Це саме той аспект діяльності, який контролює та розвиває уряд Канади, а не провінцій.

Одним 3 найвдаліших освітніх проектів для корінних жителів Австралії вважають “Залучення усієї спільноти" (The Whole of Community Engagement), ініційований університетом імені Чарльза Дарвіна у 2014 році. Його цільовою аудиторією були австралійські аборигени Північних Територій і основний акцент робився на тому, що їхнє навчання - це двосторонній процес: важливо враховувати як соціально-культурні навчальні практики спільноти, так і загальноприйняті освітні навички, опанування якими підвищує успішність індивіда на ринку праці. Завданнями такого навчання є перш за все надання корінним жителям можливості бути повноцінними і повноправними учасниками спільноти на місцевому, національному та глобальному рівнях [4].

У рамках цього проекту було відкрито навчальний центр у Сндуму, який назвали Піна Ярріньяку, що мовою Варлпірі означає “навчатися”. Цей центр пропонує гнучкий та чуйний підхід до навчання дорослих аборигенів, інтегруючи індивідуальні, сімейні та громадські пріоритети. Основною освітньою метою цього центру є підвищення грамотності дорослих.

Цей центр зосередився на таких чотирьох видах діяльності: позанавчальна, неформальна навчальна, формальна навчальна та мова i культура Варлкірі.

Позаначальна діяльність $є$ найбільш затребуваною - люди звертаються у Піна Ярріньяку з приводу багатьох питань: використання електронної пошти, пошук в Інтернеті, читання газет, спілкування в мережі, доступ до свого облікового запису myGov, заповнення бланків, отримання водійських прав або соціальної картка Охри, дзвінка з їхнього банку, отримання допомоги при прочитанні та розумінні листів із суду, інші державні послуги. Люди також люблять читати місцеві тексти, такі як Шкільний інформаційний бюлетень, Центральна земельна рада. Журнал єндумської школи “Юнга Їмі”, що означає “справжня історія”, дуже популярний, тому що наповнений історіями про спільноту за останні 30 років, із зображеннями людей і місць, які мають велике значення для читача [4].

Неформальне навчання - це освітні семінари на базі громад, де обговорюють інформацію про важливі питання спільноти. Наприклад, усвідомлення насильства в сім'ї, здорове харчування, способи створення облікових записів i розуміння законних прав. Однією 3 найпопулярніших сесій громадської освіти було вивчення кібербезпеки і способів реагування на залякування та цькування в мережі [4].

Формальне навчання - це акредитована підготовка, що надається навчальними організаціями, які приїжджають до Єндуму і зазвичай перебувають там протягом одного-двох тижнів. Більшість цих тренінгів організовується і проводиться на робочих місцях. Інші тренінги проводилися в Піна Яррінджаку. Темами тренінгів були “Спорт і відпочинок” (університет імені Чарльза Дарвіна), “Підтримка освіти” (інститут Бакалаврату), “Перша допомога психічного здоров'я” (Національна асоціація служби зайнятості) i домашнє насильство (ГО “Лайфлайн”) [4].

Напрямок проекту пов' язаний із збереженням мови та культури Варлпірі в основному вивчає твори мистецтва аборигенів, створення ресурсів грамотності Варлпірі, представлення історії та розробки артефактів у просторі навчального центру та участь у культурних заходах поза межами центру. 
Висновки. Як бачимо 3 аналізу міжнародної практики, не зважаючи на попередній негативний досвід, за останні десятиліття освіта корінного населення значно покращилась і почала відповідати філософії і потребам корінних народів. Цьому сприяло створення спеціальних умов навчання для корінних жителів та впровадження програм для покращення якості їхньої освіти. Неформальне навчання $є$ важливим для соціалізації, оскільки використання повсякденної діяльності позитивно впливає на впевненість учня у своїх діях. Особливу увагу приділяють освіті дорослих, попередньо проаналізувавши потреби конкретної місцевості, адже навчання - це двосторонній процес, при якому необхідно враховувати як соціально-культурні навчальні практики спільноти (сезонність, оповідання як основний спосіб передачі знань, дотримання їрархічності), так і загальноприйняті освітні навички, опанування якими сприяє успішності індивіда на ринку праці. Ключовий фактор успіху таких програм - врахування культурних відмінностей всіх учасників процесу та їхня практична орієнтованість.

\section{ЛІТЕРАТУРА}

1. Aboriginal Tourism Management Diploma Program: Core Curriculum Handbook Province of British Columbia, Ministry of Advanced Education, 2006. 25 p.

2. Budhwar, P. (2008). Comparative Analysis of Cultural Value Orientations of Indians and Migrant Indians in the USA International Journal of Cross Cultural Management. NY, Sage Publications, Vol. 8(1). pp. 79-105. Available at: http:// www.sagepub.co.uk/JournalsPermis sions.nav

3. Burnaby, B. (2007). Aboriginal Language Maintenance, Development and Enhancement : A Review of Literature. Stabilizing Indigenous Languages. Arizona, Northern Arizona University, pp. 21-31.

4. Burridge, N. \& Chodkiewicz, A. (2018). An Historical Overview of Aboriginal Education Policies in the Australian Context. Australian Journal of Adult Learning. Vol. 58, Number 1, pp. 125-145. DOI: 10.1007/978-94-6091-888-9_2

5. Carnoy, M. (1974). Education as cultural imperialism. London, $312 \mathrm{p}$.
6. Chaunda, Sc. Giving Voice to the Factors that Promote and Inhibit Learning in a Community. Based Multicultural Immersion Program: Adult Learner Perspectives: Implications for Research \& Practice in HRD. Texas, AERC, 2004. pp. 50-57.

7. Comprehensive Community Planning for First Nations in British Columbia: Developed by BC First Nations Community Planning Working Group. 2006. $110 \mathrm{p}$.

8. Continuing Education: Paper for Discussion at the Third National Forum on Education May, 28-30, St. John's, Newfoundland. 1998. Toronto, Council of Ministers of Education, $15 \mathrm{p}$.

9. Estimates of Aboriginal and Torres Strait Islander Australians. Australian Bureau of Statistics. 2018. Available at: abs.gov.au.

10. Grant, A. (1999). The Challenge for Universities. First Nations Education in Canada : The Circle Unfolds. Ed. by Marie Battiste, Jean Barman. Vancouver, UBC Press, 211 p.

11. McKenna, S. (2010). Aboriginal Participation in Tourism Planning in British Columbia . Ontario, University of Waterloo, $132 \mathrm{p}$.

12. Mock, K. (2001). Race Relations Training in Canada: Towards the Development of Professional Standards. Toronto. The Canadian Race Relations Foundation, $77 \mathrm{p}$.

13. Redefining How Success is Measured in First Nations, Inuit and Metis Learning: Report on Learning in Canada. Ottawa, Canadian Council on Learning, 2002. 47 p.

14. Smith, P. (2005). Demographic Effects on the Use of Vertical Sources of Guidance by Managers in Widely Differing Cultural Contexts. International Journal of Cross Cultural Management. NY, Sage Publications. Vol. 5 (1), pp. 5-26. Available at : http:/ / www.sagepublications.com

15. Transforming Communities through Tourism: A Handbook for Community Tourism Champions. BC, The Tourism and Hospitality Educational Network, 91 p. 2004. Available at : http:// www.bctorc.ca

16. University Supports for Open Access: A Canadian National Survey. Ed. by Devon Greyson, Kumiko Vezina, Heather Morrison, Donald Taylor, Charlyn Black. Canadian Journal of Higher Education. Kingston. Vol. 39, No. 3. 2009. pp. 132.

Стаття надійшла до редакції 22.05.2019

G5808

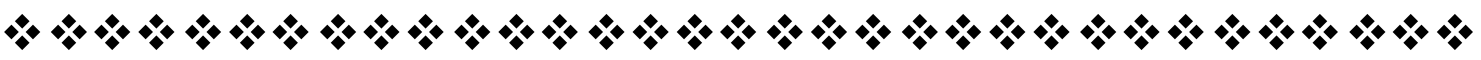

